\title{
Experiences with Reorienting Teacher Education to Address Sustainability
}

\section{Jana Dlouhá}

\author{
Envigogika 9 (2) - Informace/ Information
}

Publikováno/Published 30. 11. 2013

DOI : $\underline{10.14712 / 18023061.466}$

The $8^{\text {th }}$ Biennial Meeting of the International Network of Teacher Education Institutions (INTEI) associated with the UNESCO Chair on Reorienting Teacher Education to Address Sustainability was held in the Japanese town of Okayama on 14-17 November 2014. The meeting was hosted by the City of Okayama and the Japanese government, and involved numerous volunteers; the organizers (just like at the 2014 UNESCO World Conference on Education for Sustainable Development held prior to the Meeting) created a friendly and supportive atmosphere.

This meeting was not the first to bring together representatives of the Teacher Education Institution from around the world. The network itself was initiated in December 1997 at a UNESCO discussion in Thessaloniki where representatives from teacher-education institutions in nine countries agreed to work together as the Teacher Education Consultation (TEC). York University of Toronto, Canada, in conjunction with UNESCO subsequently established the UNITWIN/UNESCO Chair to provide advice to UNESCO and teacher training institutions on reorienting teacher training to address sustainable development. The Chair invited the TEC together with approximately 25 other institutions representing diverse geographic regions and various types (large and small, innovative and traditional) of teacher training institutions to join the network. The initial meeting and planning forum was held in Toronto, Canada, from 23-27 October 2000. Since then, the network of these approximately 30 teacher education institutions from diverse regions of the world have worked together to share experiences of effective methods of addressing SD education, to publish key findings and provide research results to other nations, ministries, and institutions - and to review this process at its biennial meetings. The Charles University Environment Centre was one of the nine institutions which formed the TEC and launched the network in 1997 and 2000 (UNITWIN, 2000).

What was this meeting which was held immediately after the 2014 UNESCO World Conference on Education for Sustainable Development about? Themes discussed during the meeting focused on teacher education and education for sustainable development (ESD), biodiversity education, and ESD's contributions to a quality education. The overall aim was to explore the roles that the INTEI will play in the new Global Action Program on ESD (GAP). To this end, three regional group discussions relevant to five regions of the world were held to review challenges and plan how to improve joint work, enhance national organizations and support quality teaching in the context of teacher education institutions. The four-day meeting combined plenary sessions for the professional development of the participants with working sessions in which participants shared their experiences, successes and challenges and also engaged in joint problem-solving. Interesting themes discussed and ideas brainstormed included outdoor education, early 
childhood care and education, professional development for ESD leaders, climate change education for SD, and ESD and indigenous education; or community-based assignments, and frameworks for self-assessment of ESD activities, etc. Local organizers also planned half-day school visits and study tours as part of the INTEI meeting program. The outcomes of the Meeting are currently being reviewed, and new cooperation is planned, e.g. in the field of research (joint themes were identified at the meeting) or in specific areas such as biodiversity education.

Cooperation with INTEI is a good chance to reflect upon opportunities provided by the teaching process itself for the transition of educational systems to meet sustainable development challenges. This is a community where enormous experience of the new pedagogies, including quality assurance, assessment and self-assessment methods, institutional transitions and leadership gathered (not only) over the ESD Decade. Many of the institutions involved were able to share their expertise concerning methodological issues; moreover, the cultural diversity represented by the INTEI members is an opportunity to explore how the concept of ESD works in different contexts, how a common understanding of sustainable development could be progressively established, and where the resources are which could possibly be used to highlight cultural and other specifics. If proper communication channels between TEIs and other HEIs concerned with sustainability issues were established, an exchange of views and experience could capitalize more from the specialist expertise of those involved so that the dialogue is enriched by their insights and the most up-to-date information (research results).

\section{References:}

UNITWIN/UNESCO Chair at York University International Network. Reorienting Teacher Education to Address Sustainability, Background Notes. March 22, 2000. 